\title{
48. A SUMMARY OF INTERSTITIAL-WATER GEOCHEMISTRY OF LEG 133 ${ }^{1}$
}

\author{
Peter K. Swart, ${ }^{2}$ Alex Isern, ${ }^{3}$ Harry Elderfield, ${ }^{4}$ and Judith A. McKenzie ${ }^{3}$
}

\begin{abstract}
The chemical compositions of the interstitial pore-water samples measured on board the JOIDES Resolution are compared with shore-based analyses of the samples' strontium, oxygen, and carbon isotopic compositions. These analyses support conclusions of large-scale water movement through the sediment overlying the Queensland Plateau at Sites 811, 812, 813, and 814 , possibly leading to massive platform dolomitization.

At the Queensland continental margin sites, complete sulfate reduction and abundant methanogenesis occurs, yet little evidence of these processes is seen in the $\delta^{13} \mathrm{C}$ of the pore waters. The failure to observe these signatures is a consequence of large-scale recrystallization of carbonate sediments masking the isotopic signatures of these processes. Although abundant igneous material is present at these sites, we do not think that significant alteration of these minerals is taking place in situ. Decreases in the $\mathrm{Mg}^{2+}$ and $\mathrm{Ca}^{2+}$ concentration result from the formation of dolomite and calcite; decreases in $\mathrm{K}^{+}$are a consequence of absorption onto clays; and decreases in the $\delta^{18} \mathrm{O}$ are caused by carbonate recrystallization, with perhaps some minor influence from the alteration of volcanic glass.

At several sites there is evidence of diffusion of saline fluids from an underlying source, presumably evaporitic in nature, but this cannot be confirmed using either $\mathrm{Sr}$ or $\mathrm{O}$ isotopic data.
\end{abstract}

\section{INTRODUCTION}

During Leg 133 of the Ocean Drilling Program (ODP), sediments were cored in three different areas off the northeastern coast of Australia. All of these areas contained periplatform sediments (Schlager and James, 1978). This type of sediment is generally found near shallow-water carbonate platforms and consists of mixtures of metastable minerals, high-Mg calcite (HMC), and aragonite, as well as low-Mg calcite (LMC). The first area includes those sites $(811,812$, $813,814,816,817,818,824,825$, and 826 ) situated on submerged carbonate platforms or on the flanks of such platforms: the Queensland and the Marion plateaus (Fig. 1). The mineralogy of the sediments at these sites is predominantly carbonate, containing only small concentrations of noncarbonate minerals such as quartz and clay minerals. The second group of sites (815 and 823) is situated in the deeper water troughs between the Queensland and the Marion plateaus and the Great Barrier Reef (Fig. 1). These sites penetrated thick sequences of mixed carbonates (predominantly LMC) and siliciclastics. The third group (Sites 821, 820,819, and 822) forms a proximal-to-distal transect from the Great Barrier Reef into the adjacent Queensland Trough (Fig. 1). This third group is situated in shallower water than is the second group and contains substantial concentrations of periplatform sediments mixed with quartz, feldspar, and clay minerals.

The aim of this paper is to synthesize the shipboard chemical data with oxygen and carbon isotopic analyses of pore waters, and to integrate them with data presented by Swart (this volume) and Elderfield et al. (this volume).

\footnotetext{
'McKenzie, J.A., Davies, PJ., Palmer-Julson, A., et al., 1993. Proc. ODP, Sci. Results, 133: College Station, TX (Ocean Drilling Program).

${ }^{2}$ Marine Geology and Geophysics, Rosenstiel School of Marine and Atmospheric Science, University of Miami, 4600 Rickenbacker Causeway, Miami, FL 33149-1098, U.S.A.

${ }^{3}$ Geologisches Institut, Eidgenossische Technische Hochschule, Sonneggstrasse 5, CH-8092, Zurich, Switzerland.

${ }^{4}$ Dept. of Earth Science, University of Cambridge, Downing St., Cambridge CB2 $3 E Q$, United Kingdom.
}

\section{METHODS}

The chemical data discussed in this paper have been presented in other papers, and, therefore, the reader is referred to these references for the appropriate analytical techniques: Davies, McKenzie, PalmerJulson, et al. (1991); Elderfield et al. (this volume); and Swart (this volume). The $\mathrm{C}$ and $\mathrm{O}$ isotopic data for the pore waters, which have not been presented previously, were obtained using the methods described in Swart (this volume).

\section{RESULTS}

A summary of all geochemical data, including the $\mathrm{Sr}, \mathrm{C}$, and $\mathrm{O}$ isotopic data as well as measured shipboard data (with the exception of ammonia, phosphate, and silica), is shown in Table 1. As a result of some analytical problems, $\mathrm{C}$ and $\mathrm{O}$ isotopic data are not available for all samples.

\section{Oxygen Isotopic Data}

\section{Sites $811,812,813$, and 816}

These sites are characterized by relatively heavy oxygen isotopic compositions in their pore waters throughout the cores (Fig. 2 and Table 1). Generally, these isotopic values lie between $+0.5 \%$ and $+1.0 \%$. Site 813 exhibits slightly depleted isotopic values relative to Sites 811 and 812 , with $\delta^{18} \mathrm{O}$ values lying between $+0.2 \%$ and $+0.5 \%$.

\section{Sites $819,820,821,822$, and 823}

These sites show an enrichment in their $\delta^{18} \mathrm{O}$ values in the upper 50 to $100 \mathrm{mbsf}$, followed by a depletion down the core. The magnitude of this depletion increases with distance from the continental margin. The most depleted $\delta^{18} \mathrm{O}$ values of $-0.97 \%$ are reached in the sediments of Site 822 at a depth of $397.50 \mathrm{mbsf}$ (Fig. 3 and Table 1). Site 823, which is actually the farthest away from the continental margin, reaches a minimum of only $-0.5 \%$ at a depth of approximately 400 mbsf. From this depth toward the base of the core at $1000 \mathrm{mbsf}$, the isotopic composition increases to $+0.5 \%$ (Fig. 4). 


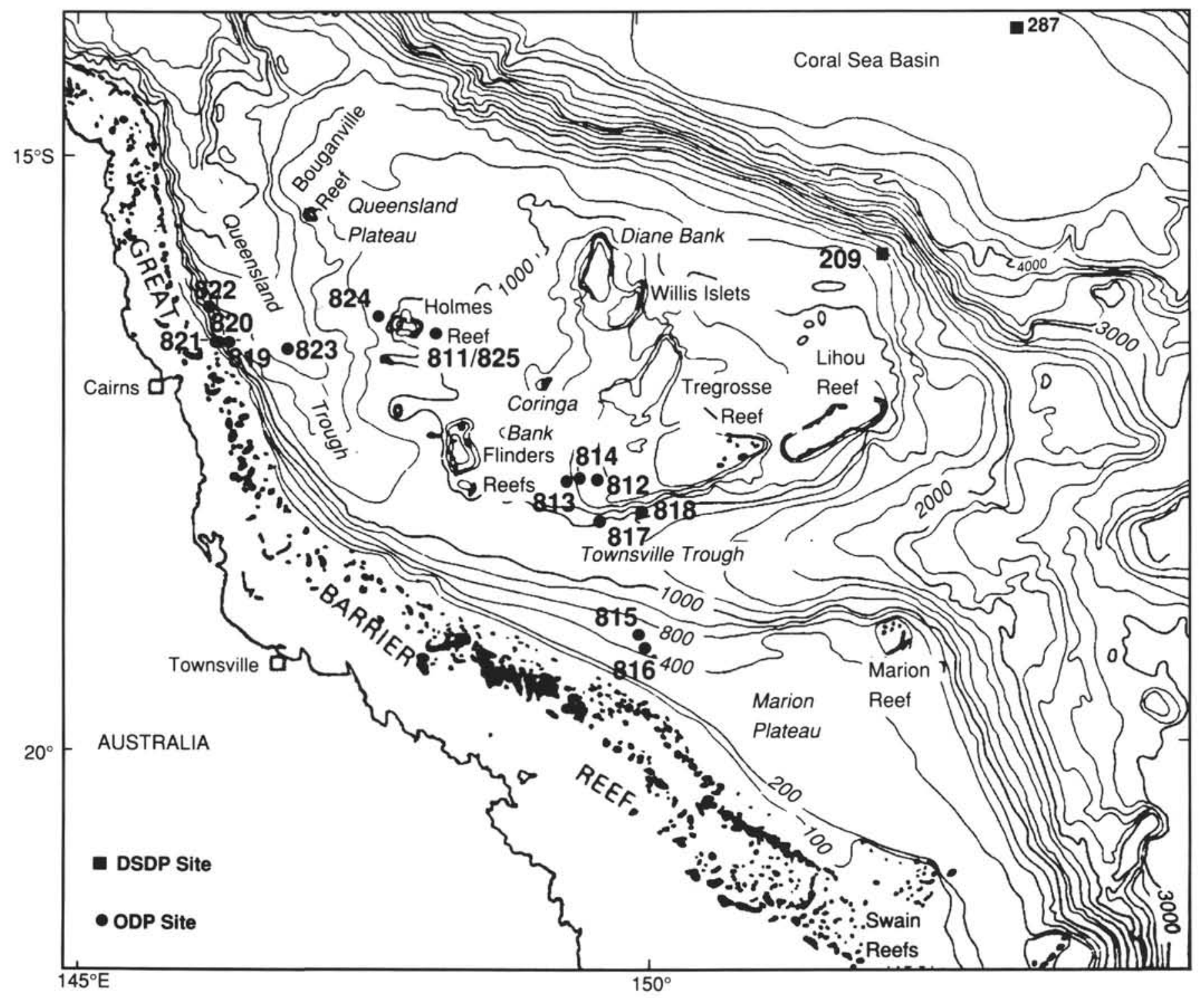

Figure 1. Location of the sites drilled during Leg 133.

\section{Site 815}

This site exhibited relatively heavy $\mathrm{O}$ isotopic compositions $(0.5 \%$ to $1.2 \%$ ) throughout the cored interval (Fig. 5 and Table 1).

\section{Carbon Isotopic Data}

Sites $811,812,813$, and 814

With the exception of the upper portion of Sites 814 and 812, these sites all exhibit slightly negative $(-1 \%)$ carbon isotopic compositions throughout (Fig. 6). Site 811 exhibits a slight enrichment down the core.

\section{Sites $819,820,821,822$, and 823}

All sites show a rapid depletion in $\delta^{13} \mathrm{C}$ in the upper 10 to $50 \mathrm{mbsf}$, followed by an enrichment down the core. Site 819 exhibits the most severe depletion, attaining a $\delta^{13} \mathrm{C}$ value of $-15 \%$ at a depth of 25.48 mbsf. These depletions are less pronounced at other sites nearer to the Great Barrier Reef. In the lower portion of the core the $\delta^{13} \mathrm{C}$ of the dissolved inorganic carbon (DIC) becomes isotopically heavier. The greatest enrichment occurs at Site 822 , where values as heavy as $+4 \%$ are reached. The magnitude of the enrichment in the lower portion of the core also changes with respect to the reef margin, being the highest at the sites farthest away from the margin (Fig. 7). In contrast to Site 822 , Site 823 does not exhibit any enrichment in $\delta^{13} \mathrm{C}$ down the core (Fig. 4 and Table 1).

\section{Site 815}

Site 815 exhibits a decrease in $\delta^{13} \mathrm{C}$ throughout the upper $50 \mathrm{mbsf}$ and maintains approximately the same isotopic composition to a depth of $350 \mathrm{mbsf}$. A slight enrichment is seen at the base of the core (Fig.5).

\section{DISCUSSION}

\section{Carbonate Platform and Flank Sites 811/825, 812, 813, $814,816,817$, and 818}

The carbonate platform and flank sites can be separated into those situated on the Queensland Plateau and those located on the Marion Plateau. Sites $811,812,813,814,824$, and 825 were cored on the Queensland Plateau and are all characterized by the present-day flux of substantial quantities of periplatform sediments (admixtures of bank-derived aragonite, HMC, and pelagic LMC). Sites 817 and 818 


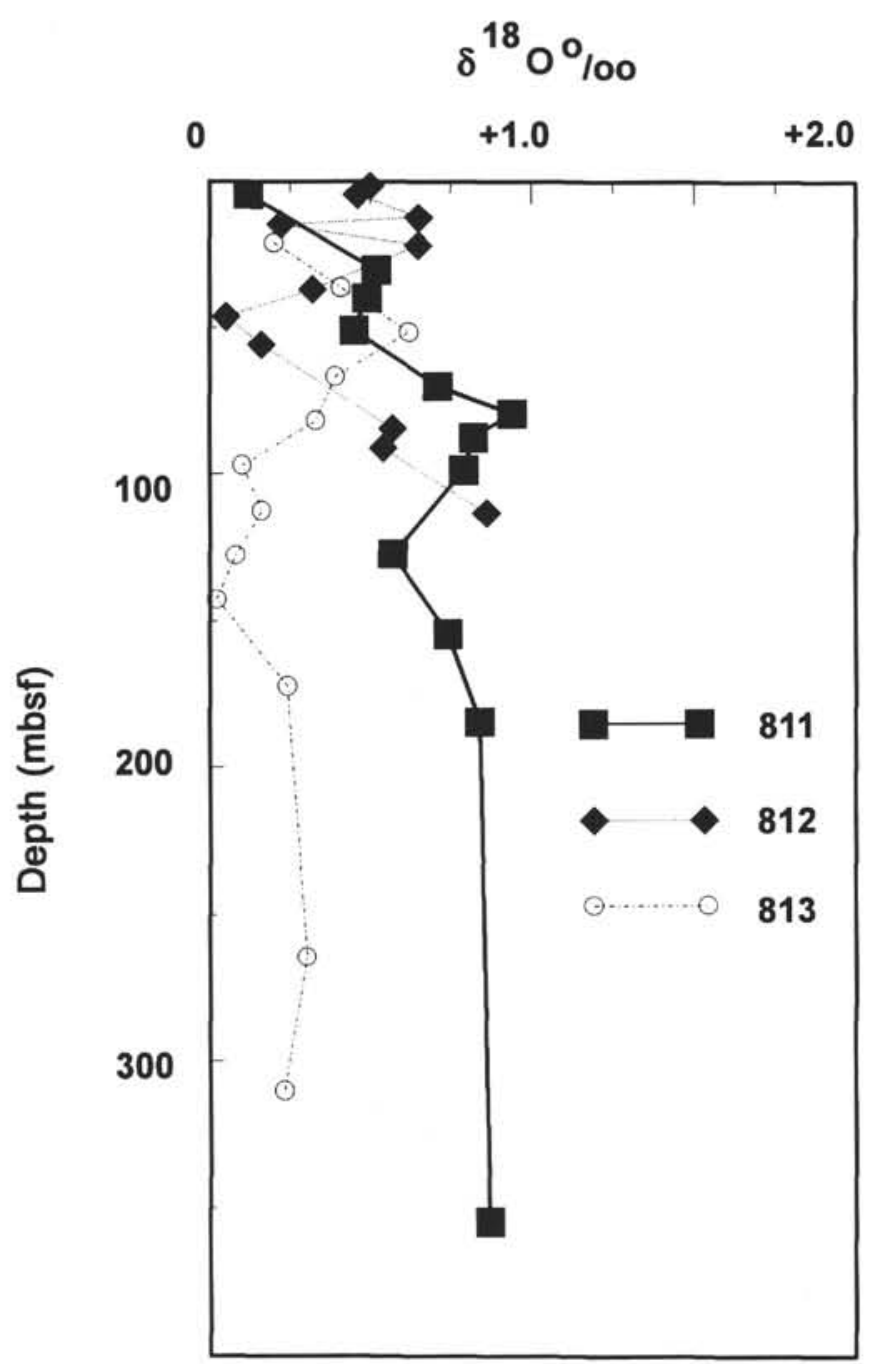

Figure 2. Oxygen isotopic data from pore waters recovered from Sites 811, 812 , and 813 .

were cored on the flanks of the Queensland Plateau. Sites 816 and 826 were drilled on the Marion Plateau.

\section{Strontium}

Previous ODP sites in the Bahamas (Leg 101) and the Maldives (Leg 115) where periplatform sediments have been cored (Swart and Guzikowski, 1988; Swart and Burns, 1990) were characterized by relatively high concentrations of $\mathrm{Sr}^{2+}$ in their interstitial pore fluids that resulted from the recrystallization of aragonite and $\mathrm{HMC}$ to LMC, and the consequent release of $\mathrm{Sr}^{2+}$ (Fig. 8). Therefore, perhaps the most surprising feature concerning the pore-water chemistry at Sites 811, 812,813 , and 814 is the absence of large increases in $\mathrm{Sr}^{2+}$ in the pore fluids, despite the fact that aragonite disappears relatively quickly with increasing depth sub-bottom (Fig. 9). We propose that fluid movement through the sediment prevents the establishment of normal diffusive $\mathrm{Sr}^{2+}$ gradients at these sites, an interpretation that can be supported by the following evidence: (1) the absence of geochemical gradients in the pore fluid; (2) the ${ }^{87} \mathrm{Sr} /{ }^{86} \mathrm{Sr}$ ratio of the pore water; and (3) the geothermal gradients. Perhaps the most persuasive evidence is the ${ }^{87} \mathrm{Sr} /{ }^{86} \mathrm{Sr}$ ratio of the pore fluid. The pore fluids from Sites 811 to 814 all have ${ }^{87} \mathrm{Sr} /{ }^{86} \mathrm{Sr}$ ratios that are much more radiogenic than the ratio of contemporaneous sediments and probably reflect mixing between
$\mathrm{Sr}$ released by recrystallization of carbonate sediments and $\mathrm{Sr}^{2+}$ contributed from modern seawater circulating through the platform (Elderfield, this volume) (Fig. 10). Such circulation does not appear to be taking place at a similar depth in the deeper flank sites, Sites 817 and 818 , or at Site 816 situated on the top of the Marion Plateau. These sites exhibit steep diffusive $\mathrm{Sr}^{2+}$ gradients (Fig. 11B) and ${ }^{87} \mathrm{Sr} /{ }^{86} \mathrm{Sr}$ profiles (Elderfield et al., this volume) similar to those described for oceanic sediments (Gieskes et al., 1986) (Fig. 11A).

\section{Oxygen and Carbon Isotopes}

Although not conclusive, the oxygen and carbon isotopic profiles of these sites support the hypothesis of fluid movement in that there is little evidence for significant carbonate recrystallization. For example, if the pore fluids were being strongly influenced by carbonate recrystallization, they would rapidly become isotopically depleted in oxygen. This is not the case. Instead, the oxygen isotopic compositions of the pore fluids are relatively heavy throughout (Fig. 2). Carbon isotopic compositions are lighter than surface seawater but presumably similar to bottom water for the area (Fig. 6). If these fluids were being affected by carbonate recrystallization, they probably would show heavier carbon isotopic compositions. In fact, both Sites 812 and 814 exhibit some isotopically heavy values in the upper portion of the core, the same interval that exhibits $\mathrm{Sr}^{2+}$ enrichment. Site 811 displays a progressive enrichment down the core. These values suggest the presence of carbonate reactions in these regions, and, possibly, the presence of different aquifers. Different aquifers in the carbonate platform also are suggested by these oxygen isotopic data.

\section{Calcium and Magnesium}

Of further interest is the nature of the $\mathrm{Ca}^{2+}, \mathrm{Mg}^{2+}$, and $\mathrm{Cl}^{-}$gradients. Sites 813 and 814 are characterized by steep $\mathrm{Ca}^{2+}$ gradients near the sediment/water interface, but relatively constant concentrations as depth increases sub-bottom. In contrast, Site 812 exhibits a constant concentration of $\mathrm{Ca}^{2+}$ as depth increases and a relatively sudden increase in $\mathrm{Ca}^{2+}$ concentration from 80 to $120 \mathrm{mbsf}$ (Fig. 9). Normally, the geochemical gradients observed at Sites 813 and 814 are indicative either of fluid movement out of these sediments or of horizontal flow parallel to the seafloor. In contrast, the gradients at Site 812 are associated with the movement of normal seawater into the formation, either vertically from the overlying seawater or in a horizontal direction. Hence, these gradients support the interpretation of fluid flow through the Queensland Plateau sites. At Sites 816,817, and $818, \mathrm{Ca}^{2+}$ gradients do not support fluid movement and, therefore, concur with the $\mathrm{Sr}^{2+}$ data.

\section{Geothermal Gradients}

The interpretation of fluid flow at the Queensland Plateau sites is supported by geothermal measurements performed during the logging of Sites 812 and 814 . Site 812 shows a relatively constant temperature of approximately $11^{\circ} \mathrm{C}$ to a depth of $200 \mathrm{mbsf}$ and then a sudden rise to a temperature of approximately $17^{\circ} \mathrm{C}$. At Site 814 there is a sharp temperature gradient close to the seawater/sediment interface. One problem with these data is that they were taken by logging immediately after drilling, and there is a considerable probability that the geothermal gradients are not representative of those normally present. Problems with these data can be seen when comparing Sites 817 and 812 , which exhibit similar geothermal gradients in the open logged hole, yet have clearly different interstitial porewater profiles. Both of these sites probably penetrated under pressured zones, causing water to flow into the hole after logging. In the case of Site 812 , this zone is probably close to the surface, thereby influencing water flow through the overlying veneer of uncemented sediments. At Site 817, however, this zone was considerably deeper; 
Table 1. Summary of interstitial pore-water data from Leg 133.

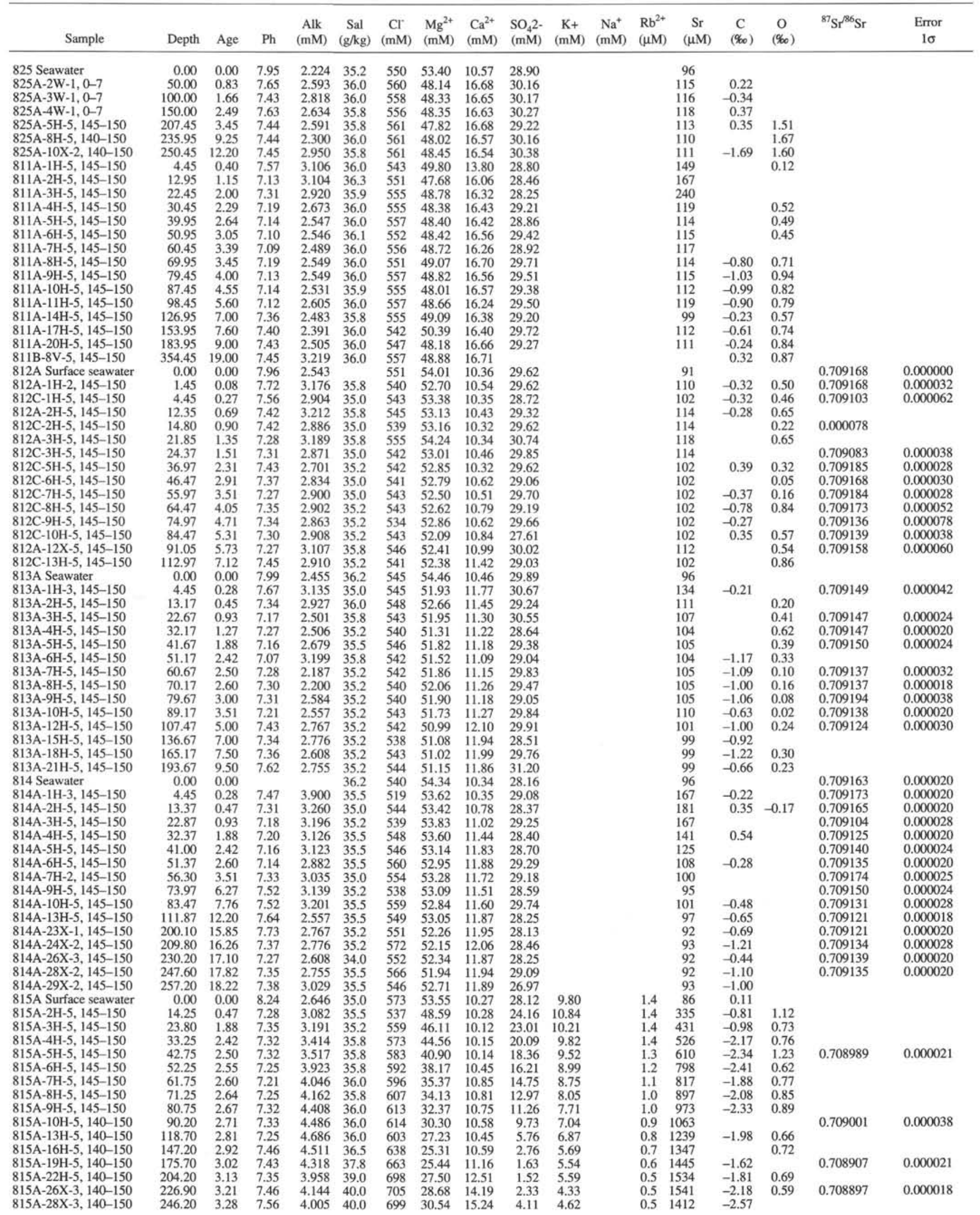


Table 1 (continued).

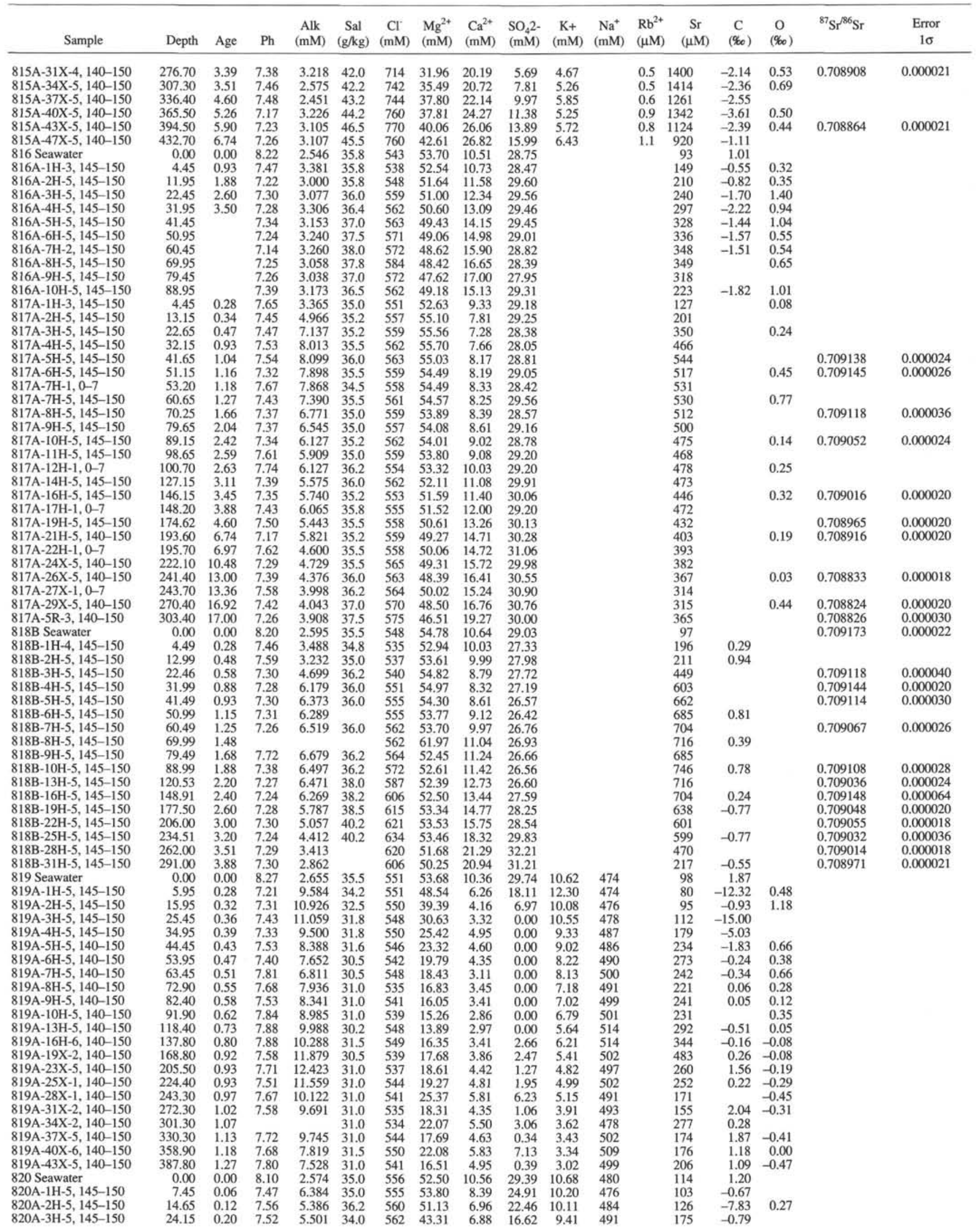


Table 1 (continued).

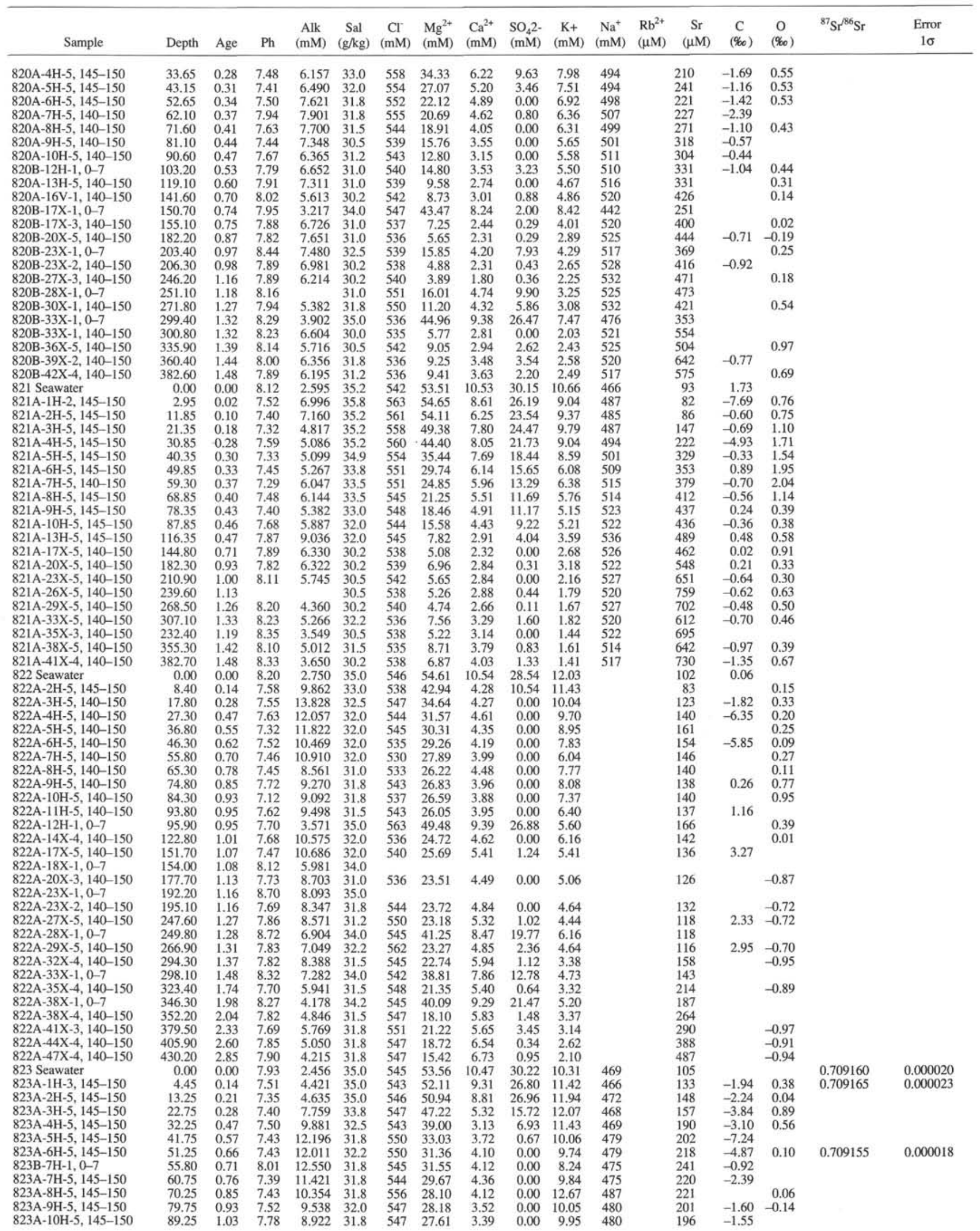




\begin{tabular}{|c|c|c|c|c|c|c|c|c|c|c|c|c|c|c|c|c|c|}
\hline Sample & Depth & Age & $\mathrm{Ph}$ & $\begin{array}{c}\text { Alk } \\
(\mathrm{mM})\end{array}$ & $\begin{array}{c}\text { Sal } \\
(\mathrm{g} / \mathrm{kg})\end{array}$ & $\underset{(\mathrm{mM})}{\mathrm{Cl}^{-}}$ & $\begin{array}{l}\mathrm{Mg}^{2+} \\
(\mathrm{mM})\end{array}$ & $\begin{array}{l}\mathrm{Ca}^{2+} \\
(\mathrm{mM})\end{array}$ & $\begin{array}{l}\mathrm{SO}_{4} 2- \\
(\mathrm{mM})\end{array}$ & $\begin{array}{c}\mathrm{K}+ \\
(\mathrm{mM})\end{array}$ & $\underset{(\mathrm{mM})}{\mathrm{Na}^{+}}$ & $\begin{array}{l}\mathrm{Rb}^{2+} \\
(\mu \mathrm{M})\end{array}$ & $\begin{array}{c}\mathrm{Sr} \\
(\mu \mathrm{M})\end{array}$ & $\begin{array}{l}C \\
\left(\%_{0}\right)\end{array}$ & $\begin{array}{c}0 \\
(\%)\end{array}$ & ${ }^{87} \mathrm{Sr}{ }^{86} \mathrm{Sr}$ & $\begin{array}{c}\text { Error } \\
1 \sigma\end{array}$ \\
\hline $823 \mathrm{~B}-12 \mathrm{H}-1,0-7$ & 103.30 & 1.17 & 8.33 & 9.912 & 31.8 & 542 & 28.42 & 4.83 & 0.43 & 5.50 & 478 & & 212 & & & & \\
\hline $823 \mathrm{~B}-12 \mathrm{H}-5,140-150$ & 110.70 & 1.24 & 7.82 & 7.745 & 32.2 & 542 & 25.91 & 3.97 & 0.00 & 8.11 & 478 & & 197 & -1.85 & 0.13 & & \\
\hline $823 \mathrm{~A}-13 \mathrm{H}-5,145-150$ & 117.95 & 1.27 & 7.87 & 7.929 & 31.8 & 545 & 25.18 & 3.97 & 0.00 & 8.24 & 483 & & 216 & -1.57 & 0.06 & & \\
\hline $823 B-15 X-5,140-150$ & 139.50 & 1.36 & 7.82 & 7.668 & 31.8 & 547 & 26.15 & 3.77 & 0.20 & 7.25 & 484 & & 234 & -0.41 & 0.04 & 0.709062 & 0.000024 \\
\hline $823 \mathrm{~B}-17 \mathrm{X}-1,0-7$ & 151.40 & 1.48 & 7.70 & 4.450 & 34.0 & 548 & 44.72 & 7.73 & 20.38 & 7.56 & 477 & & 211 & 0.61 & & & \\
\hline $823 \mathrm{~B}-18 \mathrm{X}-3,140-150$ & 165.50 & 2.29 & 7.66 & 7.651 & 31.5 & 553 & 25.98 & 4.05 & 0.65 & 6.44 & 491 & & 282 & & & & \\
\hline $823 \mathrm{~B}-21 \mathrm{X}-3,140-150$ & 194.60 & 2.34 & 7.92 & 6.824 & 32.0 & 549 & 23.74 & 4.14 & 0.00 & 8.21 & 488 & & 374 & -0.72 & -0.37 & & \\
\hline $823 \mathrm{~B}-22 \mathrm{X}-1,0-7$ & 199.80 & 2.38 & 7.59 & 7.914 & 32.2 & 547 & 25.94 & 4.74 & 0.50 & 5.58 & 485 & & 409 & & & & \\
\hline $823 \mathrm{~B}-24 \mathrm{X}-2,140-150$ & 221.60 & 2.42 & 7.76 & 6.081 & 31.8 & 547 & 20.96 & 5.14 & 0.00 & 5.25 & 491 & & 477 & -1.16 & -0.60 & 0.708990 & 0.000026 \\
\hline $823 \mathrm{~B}-26 \mathrm{X}-1,0-7$ & 237.70 & 2.60 & 8.03 & 6.822 & 33.8 & 543 & 27.50 & 5.20 & 4.32 & 4.31 & 485 & & 505 & & & & \\
\hline $823 B-27 X-6,140-150$ & 256.20 & 2.65 & 7.86 & 5.968 & 31.8 & 548 & 21.41 & 3.81 & 0.00 & 4.73 & 494 & & 432 & -1.14 & & & \\
\hline $823 \mathrm{~B}-30 \mathrm{X}-2,140-150$ & 279.20 & 2.87 & 7.82 & 4.959 & 31.8 & 552 & 21.87 & 3.80 & 0.35 & 4.39 & 497 & & 619 & & -0.30 & 0.708962 & 0.000018 \\
\hline $823 \mathrm{~B}-32 \mathrm{X}-1,0-7$ & 295.60 & 3.03 & 8.03 & 5.752 & 31.8 & 543 & 23.73 & 5.96 & 3.60 & 3.66 & 489 & & 662 & & & & \\
\hline $823 \mathrm{~B}-33 \mathrm{X}-4,140-150$ & 311.20 & 3.18 & 7.91 & 3.780 & 32.0 & 546 & 20.44 & 5.21 & 2.42 & 3.98 & 495 & & 687 & -2.52 & -0.35 & & \\
\hline $823 \mathrm{~B}-36 \mathrm{X}-5,140-150$ & 341.60 & 3.48 & 7.91 & 3.068 & 31.8 & 558 & 18.45 & 4.82 & 0.04 & 4.43 & 506 & & 703 & -0.85 & -0.33 & & \\
\hline $823 \mathrm{~B}-39 \mathrm{X}-5,140-150$ & 370.40 & 3.51 & 7.97 & 3.537 & 31.8 & 554 & 19.16 & 4.64 & 0.00 & 3.49 & 502 & & 654 & -1.18 & -0.51 & 0.708878 & 0.000026 \\
\hline $823 B-42 X-4,140-150$ & 397.90 & 3.70 & 7.84 & 3.893 & 31.8 & 551 & 18.67 & 5.73 & 0.45 & 2.95 & 499 & & 742 & -1.18 & -0.50 & 0.708846 & 0.000040 \\
\hline $823 B-45 X-5,140-150$ & 428.30 & 3.88 & 7.73 & 3.528 & 31.8 & 549 & 17.23 & 5.67 & 0.00 & 2.84 & 498 & & 825 & -3.03 & -0.58 & 0.708840 & 0.000030 \\
\hline $823 B-48 X-4,140-150$ & 455.80 & 3.95 & 7.70 & 2.950 & 31.8 & 556 & 15.81 & 6.16 & 0.19 & 2.60 & 508 & & 1029 & 0.56 & -0.11 & & \\
\hline $823 B-52 X-4,140-150$ & 493.70 & 4.15 & 7.83 & 2.838 & 31.8 & 560 & 13.26 & 7.41 & 0.00 & 2.45 & 514 & & 1185 & -1.59 & -0.52 & 0.708855 & 0.000030 \\
\hline $823 B-55 X-5,140-150$ & 525.20 & 4.24 & & & 32.0 & 557 & 12.99 & 7.91 & 0.00 & 1.70 & 508 & & 1269 & -1.64 & -0.50 & 0.708878 & 0.000026 \\
\hline 823B-58X-5, 140-150 & 552.80 & 4.40 & 7.87 & 2.431 & 32.0 & 560 & 13.12 & 8.43 & 0.48 & 1.69 & 513 & & 1338 & & 0.04 & 0.708904 & 0.000024 \\
\hline $823 \mathrm{~B}-61 \mathrm{X}-5,135-150$ & 581.65 & 4.50 & 7.72 & 2.335 & 32.2 & & & & & & & & & -1.43 & & 0.708879 & 0.000028 \\
\hline $823 \mathrm{~B}-64 \mathrm{X}-1,135-150$ & 604.55 & 4.60 & 7.91 & 2.081 & 32.2 & 563 & 13.71 & 9.00 & 1.08 & 2.27 & 513 & & 1515 & -1.51 & -0.48 & 0.708850 & 0.000022 \\
\hline $823 B-67 X-5,135-150$ & 639.55 & 5.06 & 7.90 & 1.836 & 32.2 & 571 & 14.18 & 9.29 & 0.69 & 2.25 & 519 & & 1780 & & -0.42 & & \\
\hline $823 \mathrm{~B}-70 \mathrm{X}-5,110-125$ & 667.70 & 5.26 & 7.81 & 1.897 & 32.2 & 568 & 13.42 & 10.27 & 1.20 & 2.33 & 515 & & 1879 & & -0.37 & & \\
\hline $823 \mathrm{~B}-73 \mathrm{X}-2,135-150$ & 692.45 & 5.40 & 7.87 & 1.910 & 32.2 & 572 & 14.40 & 10.75 & 1.14 & 2.44 & 515 & & 1913 & & -0.15 & 0.708884 & 0.000034 \\
\hline $823 \mathrm{~B}-76 \mathrm{X}-4,135-150$ & 724.45 & 5.60 & 7.79 & 2.848 & 32.2 & 568 & 14.02 & 11.91 & 0.55 & 2.28 & 510 & & 2248 & -3.86 & & 0.708879 & 0.000022 \\
\hline $823 \mathrm{~B}-79 \mathrm{X}-4,135-150$ & 753.45 & 5.90 & 7.70 & 2.680 & 32.4 & 572 & 14.54 & 13.42 & 1.37 & 2.65 & 511 & & 2335 & & -0.17 & & \\
\hline $823 \mathrm{~B}-82 \mathrm{X}-1,135-150$ & 778.05 & 6.31 & 7.56 & 3.181 & 32.5 & 568 & 16.60 & 12.24 & 1.96 & 2.13 & 507 & & 2410 & & -0.11 & & \\
\hline $823 \mathrm{C}-1 \mathrm{R}-3,130-150$ & 788.30 & 6.48 & 7.91 & 2.258 & 32.5 & 569 & 17.15 & 12.25 & 2.60 & 3.10 & 507 & & 2162 & -2.22 & -0.07 & & \\
\hline $823 \mathrm{C}-4 \mathrm{R}-1,130-150$ & 913.90 & 8.54 & & & 33.0 & 571 & 17.65 & 13.63 & 2.79 & 3.73 & 505 & & 2023 & & & & \\
\hline $823 \mathrm{C}-7 \mathrm{R}-2,130-150$ & 844.50 & 7.40 & & & 33.8 & 566 & 18.95 & 14.70 & 2.92 & 3.75 & 495 & & 2248 & & 0.00 & & \\
\hline $823 \mathrm{C}-10 \mathrm{R}-1,125-150$ & 872.05 & 7.85 & & & 33.8 & 576 & 17.05 & 16.17 & 1.92 & 2.74 & 504 & & 2444 & & 0.16 & & \\
\hline $823 \mathrm{C}-13 \mathrm{R}-4,130-150$ & 905.50 & 8.40 & & & 35.0 & 576 & 16.60 & 17.70 & 1.78 & 2.34 & 501 & & 2785 & & 0.14 & & \\
\hline $823 \mathrm{C}-16 \mathrm{R}-4,130-150$ & 934.60 & 8.88 & & & 35.0 & 570 & 18.57 & 18.11 & 2.84 & 2.16 & 494 & & 2774 & & & & \\
\hline $823 \mathrm{C}-19 \mathrm{R}-3,130-150$ & 961.60 & 9.33 & & & 34.0 & 577 & 20.33 & 19.77 & 3.97 & 2.88 & 495 & & 2750 & & 0.36 & 0.708819 & 0.000018 \\
\hline $823 \mathrm{C}-22 \mathrm{R}-3,130-150$ & 990.50 & 11.60 & & & 33.8 & 570 & 21.88 & 18.00 & 5.63 & 3.68 & 491 & & 2877 & & 1.47 & 0.708804 & 0.000018 \\
\hline 824 Seawater & 0.00 & 0.00 & 7.99 & 2.745 & 35.2 & 556 & 54.87 & 10.44 & 29.41 & 10.30 & & & 110 & & & 0.709160 & 0.000020 \\
\hline $824 \mathrm{~B}-1 \mathrm{H}-2,145-150$ & 2.95 & 0.03 & 7.62 & 3.650 & 35.0 & 541 & 54.12 & 10.30 & 29.19 & 12.17 & & & 203 & 2.24 & 0.20 & 0.709142 & 0.000026 \\
\hline $824 \mathrm{~B}-2 \mathrm{H}-5,145-150$ & 12.45 & 0.12 & 7.37 & 3.406 & 35.5 & 541 & 54.72 & 10.06 & 29.62 & 10.81 & & & 323 & 0.78 & 0.19 & 0.709172 & 0.000026 \\
\hline $824 \mathrm{~B}-3 \mathrm{H}-5,145-150$ & 21.95 & 0.20 & 7.40 & 3.388 & 35.2 & 542 & 54.16 & 10.30 & 29.67 & 10.43 & & & 326 & & 0.27 & 0.709192 & 0.000026 \\
\hline $824 \mathrm{~B}-4 \mathrm{H}-5,145-150$ & 31.45 & 0.29 & 7.60 & 2.994 & 35.2 & 542 & 54.11 & 10.26 & 29.73 & 10.17 & & & 249 & & 0.24 & 0.709124 & 0.000036 \\
\hline $824 \mathrm{~B}-5 \mathrm{H}-5,145-150$ & 40.95 & 0.38 & 7.58 & 3.066 & 35.2 & 541 & 54.29 & 10.37 & 29.20 & 11.68 & & & 285 & & & 0.709107 & 0.000034 \\
\hline $824 \mathrm{~B}-6 \mathrm{H}-5,145-150$ & 50.45 & 0.47 & 7.41 & 3.064 & 35.2 & 539 & 53.97 & 10.45 & 29.00 & 10.35 & & & 208 & 0.84 & 0.10 & 0.709100 & 0.000032 \\
\hline $824 \mathrm{~A}-1 \mathrm{H}-5,140-150$ & 57.40 & 0.63 & 7.57 & 3.339 & 35.0 & 548 & 54.19 & 10.47 & 29.52 & 11.48 & & & 277 & -0.60 & 0.20 & 0.709120 & 0.000022 \\
\hline $824 \mathrm{~A}-2 \mathrm{H}-5,140-150$ & 66.90 & 0.84 & 7.35 & 3.037 & 35.0 & 546 & 54.81 & 10.50 & 28.97 & 10.71 & & & 271 & & & 0.709108 & 0.000022 \\
\hline $824 \mathrm{~A}-3 \mathrm{H}-4,140-150$ & 74.90 & 1.02 & 7.29 & 3.375 & 35.0 & 541 & 54.29 & 10.46 & 30.00 & 9.85 & & & 270 & & & 0.709127 & 0.000044 \\
\hline $824 \mathrm{~A}-5 \mathrm{H}-5,140-150$ & 95.40 & 1.48 & 7.69 & 2.906 & 35.0 & 541 & 53.23 & 10.49 & 29.89 & 10.11 & & & 265 & 1.24 & & 0.709111 & 0.000022 \\
\hline $824 \mathrm{~A}-8 \mathrm{H}-2,140-150$ & 119.40 & 2.00 & 7.62 & 3.100 & 35.0 & 546 & 53.83 & 10.67 & 29.38 & 10.26 & & & 280 & 1.22 & & 0.709116 & 0.000018 \\
\hline $824 \mathrm{~A}-14 \mathrm{H}-5,140-150$ & 173.10 & 5.26 & 7.52 & 2.973 & 35.0 & 551 & 54.45 & 10.74 & 29.63 & 11.07 & & & 223 & & 0.19 & 0.709112 & 0.000024 \\
\hline $824 \mathrm{~A}-17 \mathrm{X}-2,145-150$ & 195.50 & 6.00 & 7.63 & 3.106 & 35.8 & 556 & 55.58 & 10.74 & 30.47 & 11.89 & & & 212 & 0.24 & & & \\
\hline $824 \mathrm{~A}-21 \mathrm{X}-2,140-150$ & 235.60 & 8.00 & 7.65 & 3.062 & 35.8 & 560 & 55.68 & 10.79 & 29.96 & 11.30 & & & 234 & 1.11 & -0.02 & 0.709090 & 0.000028 \\
\hline
\end{tabular}

therefore, no significant vertical flow down through the sediments appears to be taking place. The actual geothermal gradient at Site 817 was measured in the sediments using the WSTP tool and found to be $57^{\circ} \mathrm{C} / \mathrm{km}$. In contrast, at Site $825 / 811$, the gradient was slightly higher at $80^{\circ} \mathrm{C} / \mathrm{km}$.

In conclusion, although the temperatures obtained during logging do suggest the presence of over- and underpressured zones in the sediments, these data do not reflect the geothermal gradients actually present in the sediments and, therefore, cannot be taken to be indicative of water flow. The slight differences between Sites 825 and 817 indicate the presence of different geothermal gradients, which may be sufficient to induce circulation. To further confirm the presence of geothermally driven water flow, an extensive heat flow survey should be conducted over the Queensland Plateau.

\section{Deep Trough Sites: 815 and 823}

The overall geochemistry of Sites 815 and 823 is dominated by: (1) intense sulfate reduction and carbonate recrystallization in the upper portion of the sediment column; and (2) the increasing salinity of the pore fluids with increasing depth. At Site 815, the concentration of $\mathrm{Ca}^{2+}$ remains constant throughout the upper $200 \mathrm{mbsf}$. Throughout this same interval, the concentration of $\mathrm{Mg}^{2+}$ decreases to $26 \mathrm{mM}$,
$\mathrm{Sr}^{2+}$ increases to $1400 \mu \mathrm{M}$, and $\mathrm{SO}_{4}^{2-}$ decreases to $2 \mathrm{mM}$. Below 200 mbsf, the concentration of all components, with the exception of $\mathrm{Sr}^{2+}$, increases to the bottom of the core ( $473 \mathrm{mbsf})$. The decrease in $\mathrm{Sr}^{2+}$ occurs because of the increase in $\mathrm{SO}_{4}^{2-}$, which in turn causes the mineral celestite to become supersaturated. In contrast, Site 823 penetrated 1103 mbsf and exhibits much more pronounced decreases in $\mathrm{Ca}^{2+}, \mathrm{Mg}^{2+}$, and $\mathrm{K}^{+}$. Site 823 also contains a much lower carbonate content and, consequently, a higher concentration of clay minerals. Site 823 also exhibits an increase in the salinity of the pore fluids in the lower portions of the hole, but at a reduced rate compared with that at Site 815 . The change in $\delta^{18} \mathrm{O}$ from -0.5 to +0.5 is much greater at Site 823 than at Site 815 , which possesses heavy oxygen isotopic values throughout.

It has been suggested that the general increase in chlorinity at Sites 815 and 823 resulted from the diffusion of salts from an underlying evaporite unit (Davies, McKenzie, Palmer-Julson, et al., 1991). Increases in $\mathrm{Cl}^{-}$also were observed at Sites 817, 818, and 822 (Fig. 12). Such a common trend suggests that perhaps the evaporitic unit postulated to underlie Sites 815 and 823 may be an extensive feature of the Queensland Trough. Such a deposit has not as yet been identified in the Townsville Trough, but is known in sediments of Oligocene age in the Capricorn Basin approximately $100 \mathrm{~km}$ to the south (Ericson, 1976). 


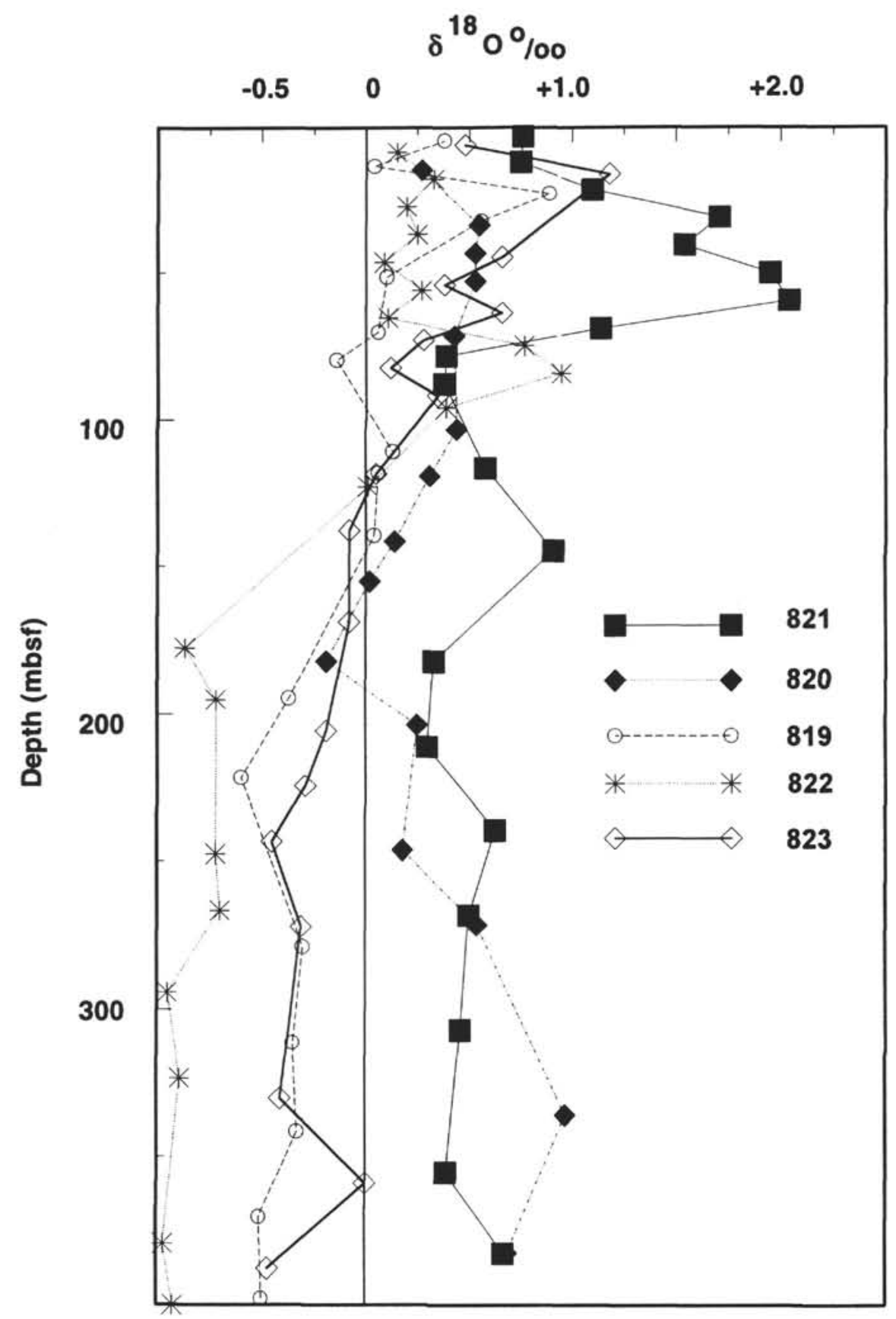

Figure 3. Oxygen isotopic data from pore waters recovered from Sites $819,820,821,822$, and 823 .

Diffusion from an underlying saline source is neither supported nor refuted by stable $\mathrm{O}$ and $\mathrm{C}$ isotopic data. At Site 815 , the $\delta^{18} \mathrm{O}$ is isotopically enriched throughout the entire core and shows no significant changes in the lower portion of the core corresponding to the salinity increase. The $\delta^{13} \mathrm{C}$ exhibits a slight increase in the lower samples. At Site 823 , the $\delta^{18} \mathrm{O}$ shows an increase in the lower portion, although this cannot be definitively ascribed to the chlorinity changes and may be a result of recrystallization at higher temperatures.

Site 823 exhibits perhaps the highest concentration of $\mathrm{Sr}^{2+}$ yet measured in pore waters from either the ODP or DSDP drilling. Concentrations as high as $2774 \mu \mathrm{M}$ are reached at $934.6 \mathrm{mbsf}$. These fluids are still below celestite saturation, as the sulfate has been completely depleted. These high values are reached as a result of the relatively low permeability of the sediments, combined with the absence of sulfate and the continued recrystallization of the carbonate sediments.

\section{Great Barrier Reef Margin Sites}

Sites $822,819,820$, and 821 form a distal-to-proximal transect off the eastern margin of the Queensland continental margin. The sediments are composed primarily of mixtures of periplatform carbonates derived from the Great Barrier Reef and quartz, feldspars, and clay minerals eroded from the Australian mainland. The concentration of clay minerals increases with increasing distance from the continental shelf, making up more than $50 \%$ of the sediments at Sites 819 and 820 . Quartz usually composes between $10 \%$ and $20 \%$ of the sediments at each site, although the proximal sites have a slight tendency 


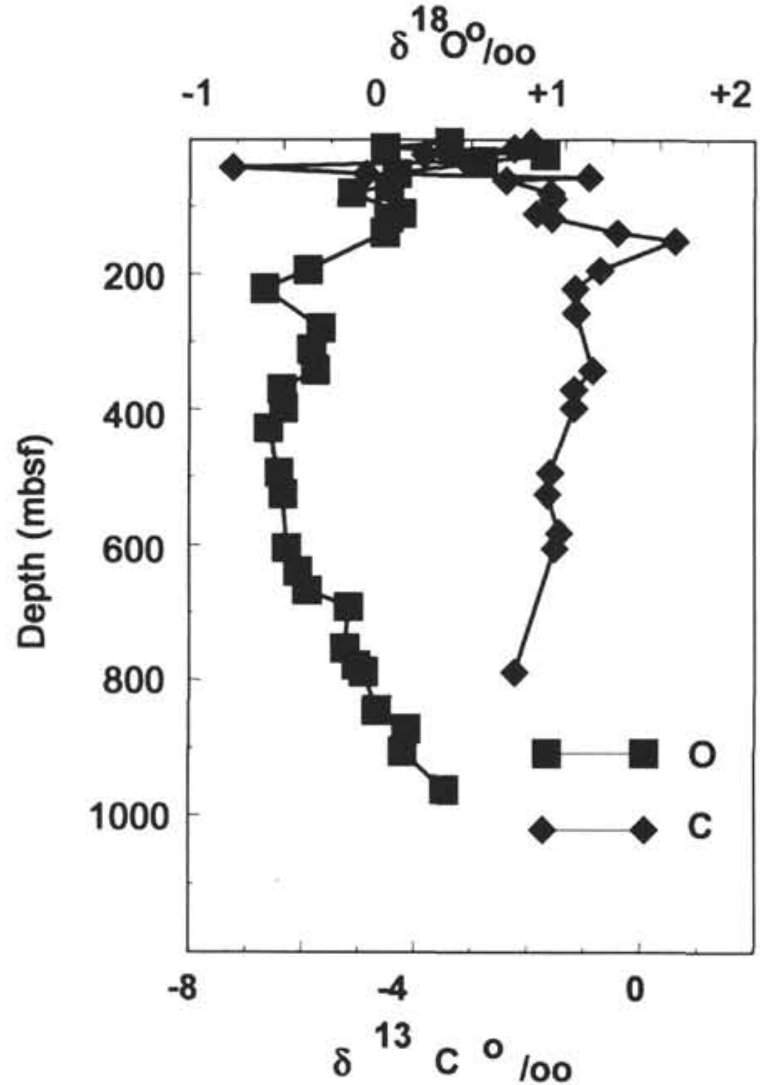

Figure 4. Oxygen and carbon isotopic data from pore waters from Site 823.

to contain higher concentrations. The clay minerals mainly consist of kaolinite and illite, and the feldspars are principally albite.

\section{Calcium, Magnesium, Potassium, Strontium, and Oxygen Isotopes}

Decreases in the concentrations of $\mathrm{K}^{+}$and $\mathrm{Mg}^{2+}$ and increases in $\mathrm{Na}^{+}$concentration were attributed to the diagenesis of igneous minerals (Davies, McKenzie, Palmer-Julson, et al., 1991). In addition, data presented in this study show a depletion in $\delta^{18} \mathrm{O}$ in the pore fluids. In previous work, depletions in the concentrations of $\mathrm{K}^{+}, \mathrm{Mg}^{2+}$, and $\delta^{18} \mathrm{O}$, as well as increases in $\mathrm{Ca}^{2+}$, have been attributed to alteration of Layer 2 basalts or volcanic material within the sediments to clay minerals or zeolites at elevated temperatures (Lawrence et al., 1976; Perry et al., 1976). As the Leg 133 sites are not located immediately over basement, reactions responsible for the depletion in $\mathrm{Mg}^{2+}, \mathrm{K}^{+}$. and $\delta^{18} \mathrm{O}$ and the decrease in $\mathrm{Ca}^{2+}$ must be taking place within the sediments (Fig. 13). Because the maximum temperature of the sediments cored is probably less than $50^{\circ} \mathrm{C}$, it is unlikely that the alteration of clay minerals, as originally suggested (Davies, McKenzie, PalmerJulson, et al., 1991), can be invoked to account for the geochemical changes observed in the pore waters. One possible explanation for the decrease in $\mathrm{K}^{+}$and increase in $\mathrm{Na}^{+}$involves absorption and desorption from illite (Hoffman, 1979). Although changes in the $\delta^{18} \mathrm{O}$ of the pore waters then could be explained by the alteration of volcanic glass, the observed decrease also could be a result of recrystallization of the relatively isotopically light precursor carbonate in colder waters. For example, Figure 14 shows the evolution of pore water in a closed system as it is subject to carbonate recrystallization. The equations used to construct these plots have been taken from Killingley (1983). In each of the three cases, the isotopic composition of the initial water has been set at $+0.5 \%$ standard mean ocean water (SMOW), the bottom temperature at $10^{\circ} \mathrm{C}$, and the geothermal gradient at $57^{\circ} \mathrm{C} / \mathrm{km}$ (data taken from Davies, McKenzie, Palmer-Julson, et al., 1991). It

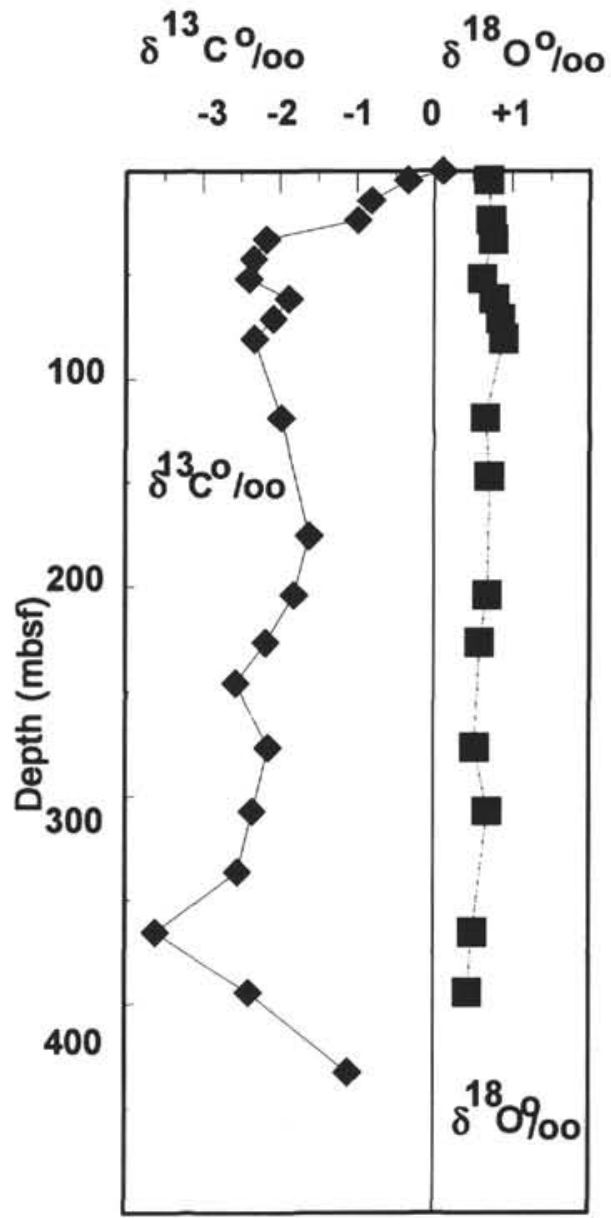

Figure 5. Oxygen and carbon isotopic data recovered from pore waters at Site 815.

is assumed that $100 \%$ recrystallization occurs by $400 \mathrm{mbsf}$ and that once carbonate has been recrystallized it no longer reacts with the pore fluid. The difference among the three lines in Figure 14 represents differing isotopic compositions of the precursor. As may be observed, each case shows a depletion with depth. These calculations are in some ways similar to the measured data shown in Figure 3. Obviously, some discrepancies exist, such as the elevated isotopic composition at Site 821. This may be a result of fossil water trapped in the sediment. In addition, Site 821 exhibits the steepest $\mathrm{Sr}^{2+}$ gradients and, hence, the highest amount of carbonate recrystallization. However, this site does not exhibit as significant a depletion in the $\delta^{18} \mathrm{O}$ as at Sites 819 and 822 , which on the basis of their $\mathrm{Sr}^{2+}$ gradients should show lower rates of recrystallization. Explanation for these differences may lie in the different isotopic composition of the precursor, differences in the isotopic composition of the water, differences in the rate of recrystallization, and even some degree of alteration of volcanic glasses.

All the continental margin sites have heavy $\delta^{18} \mathrm{O}$ values in the upper 50 to $100 \mathrm{mbsf}$. We think that these heavy values are related to the original isotopic composition of the pore fluids formed on the adjacent continental shelf area.

\section{Oxidation of Organic Material}

The rapid rate of sedimentation at Sites 819 to 822 (100 to 200 $\mathrm{m} / \mathrm{m}$.y.) has resulted in the burial of organic material that has been subsequently oxidized by sulfate-reducing bacteria to produce $\mathrm{H}_{2} \mathrm{~S}$ and $\mathrm{CO}_{2}$. In turn, these gases have been instrumental in the precipitation of pyrite, dolomite, and calcium carbonate. As the types and 


\section{$\delta^{13} \mathrm{C}^{\circ} \%$}

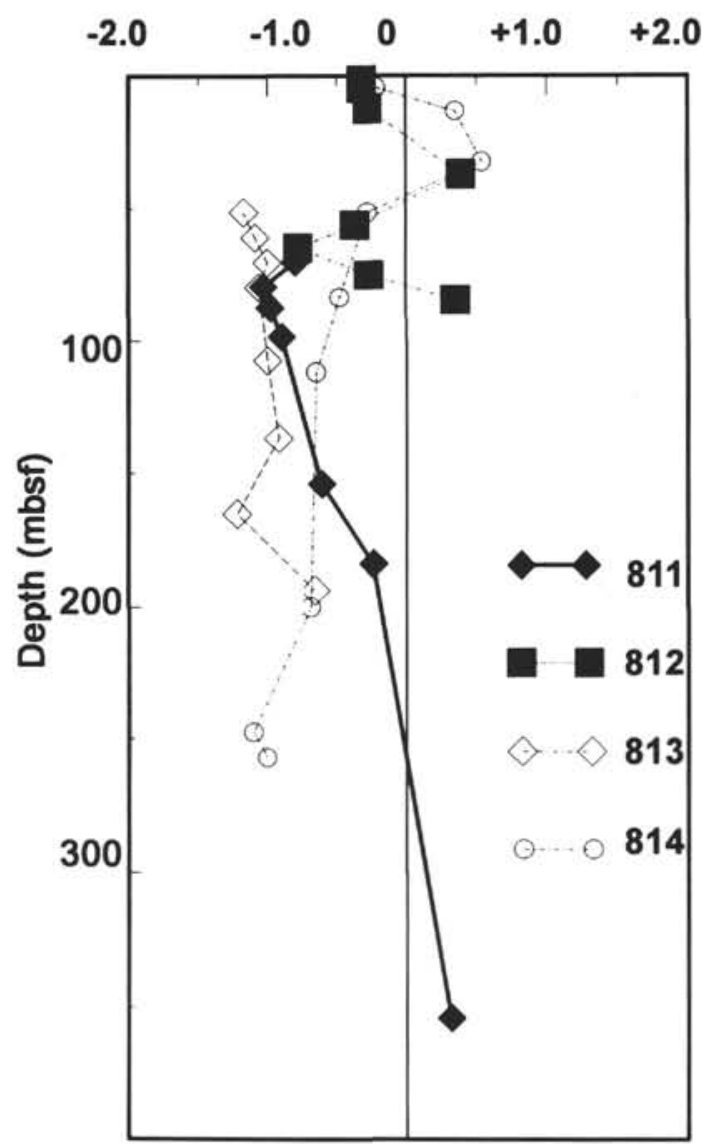

Figure 6. Carbon isotopic data from pore waters at Sites 811 through 814 .

amount of minerals and organic material vary with distance from the shelf, the nature and magnitude of the diagenetic reactions occurring in the sediments also change, producing distinctive differences in the profiles of the interstitial minor elements at the four sites.

The most dramatic change visible at all sites is the removal of sulfate during the processes of organic material oxidation (Fig. 7). Although complete sulfate reduction occurs at all sites, it takes place as shallow as 25 mbsf at Sites 822 and 819, while at Site 821, sulfate is not completely exhausted until 144.5 mbsf. Small amounts of sulfate detected in the pore fluids below the sulfate depletion zone are thought to be a result of contamination. As all sites have experienced approximately similar rates of sedimentation and do not exhibit significant differences in their physical properties (permeability, density etc.), the most plausible explanation for the different depths of sulfate reduction lies in the different amounts and types of organic material present at each site. Sites 819 and 822 must have initially contained higher concentrations of organic matter or material that was more easily degraded than that at Sites 821 and 820 . This initial difference is reflected in the present content of organic material at these sites; the organic material increases with increasing distance from the continental shelf. A further possibility is that, because the organic material at Sites 819 and 822 is predominantly of a marine rather than a terrestrial origin, it is more easily degraded by sulfatereducing bacteria. Such a difference would promote higher rates of sulfate reduction at the distal sites. The difference in the rate of sulfate reduction is partially reflected in the variations in alkalinity, with the highest values occurring at Sites 819 and 822 . The increase in alka- linity at these sites, however, is significantly less than that which might be expected as a result of sulfate reduction alone. This alkalinity deficit can be explained by: (1) the precipitation of dolomite and calcite; (2) loss of $\mathrm{H}_{2} \mathrm{~S}$ during the precipitation of pyrite.

Beneath the zone of sulfate reduction, large increases occur in the concentrations of methane. It has been suggested that these changes in the concentration might influence the $\delta^{13} \mathrm{C}$ of the DIC and the consequent isotopic composition of diagenetic calcite and dolomite. However, although there were small depletions in the $\delta^{13} \mathrm{C}$ of the DIC, there were no large changes as might have been expected based on the theories of Irwin et al. (1977) (Fig. 7). In fact, the most negative values in the sulfate reduction zone occurred at Site 819 , and the smallest depletions at Site 821 . It has been suggested that the absence of negative isotopic compositions resulted from the system being heavily buffered by carbonate minerals (Swart, this volume).

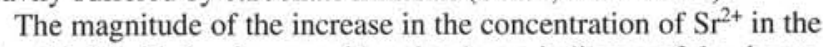
interstitial fluids is often considered to be an indicator of the degree of carbonate recrystallization. If this is the case, then the amount of carbonate crystallization increases from the distal toward the proximal sites (Fig. 9). This observation supports the interpretation of the carbon isotopic data, which shows the smallest depletion in $\delta^{13} \mathrm{C}$ at the proximal sites in the sulfate reduction zone and the smallest enrichment in the methanogenesis zone. Hence, the greater depletion in $\delta^{13} \mathrm{C}$ seen at the distal sites and the higher isotopic compositions attained in the lower portions suggest that carbonate recrystallization is less important at these sites.

Accompanying these changes in pore-water chemistry is an increase in the concentration of dolomite from the distal to proximal sites (Davies, McKenzie, Palmer-Julson, et al., 1991). Therefore, the sites having the greatest degree of sulfate reduction and the highest alkalinity have the lowest concentrations of dolomite. Such a distribution is contrary to current hypotheses (Baker and Kastner, 1981) that dolomitization may be favored by high concentrations of alkalinity and low amounts of sulfate (Swart, this volume).

\section{CONCLUSIONS}

Pore fluids from Leg 133 can be separated into three groups on the basis of the processes that are postulated to control their composition.

1. Pore fluids from the Queensland Plateau sites are characterized by an absence of geochemical gradients, by modern strontium isotopic ratios, and, in some instances, by unusual geothermal gradients. These suggest the presence of significant fluid flow through the Queensland Plateau. The absence of a depletion in the $\delta^{18} \mathrm{O}$ value of the pore waters and the slightly negative $\delta^{13} \mathrm{C}$ values support the interpretation of fluid movement. The deeper flank sites (Sites 817 and 818) do not show evidence of fluid movement through the upper periplatform portion of the section. However, at Site 817, an underpressured zone was drilled that caused water to be drawn into the hole during drilling, suggesting the penetration of a fluid conduit.

2. The deeper trough sites (Sites 815 and 823 ) have exhibited diffusive control of pore-water constituents, combined with significant amounts of carbonate recrystallization. In the lower portion of the section, chloride concentrations increased together with the concentrations of various other constituents. These increases suggest the presence of an underlying evaporite unit. Such increases also were visible in the lower portions of Sites 817 and 818 .

3. The Queensland continental margin sites are characterized by increasing rates of carbonate mineral diagenesis toward the Great Barrier Reef. In spite of total sulfate reduction and high rates of methanogenesis at these sites, little evidence could be ascertained of these processes in the $\delta^{13} \mathrm{C}$ of the pore waters or in the isotopic composition of the diagenetic minerals. The isotopic signatures of sulfate reduction and methanogenesis were more evident in the distal sites. Although significant depletion in the $\mathrm{Ca}^{2+}, \mathrm{Mg}^{2+}, \mathrm{K}^{+}$, and $\delta^{18} \mathrm{O}$ content of the pore fluids was seen, only a decrease in $\mathrm{K}^{+}$and an 
increase in $\mathrm{Na}^{+}$can be ascribed to interaction with clay minerals or formation of clay minerals from volcanic glasses.

\section{ACKNOWLEDGMENTS}

The authors would like to thank the technicians, scientists, and crew of Leg 133 for continued help throughout the cruise. Joe Powers, Joe DeMorett, and Scott Chaffey are especially thanked for their help in the chemistry laboratory. Help with the analyses was provided by Amel Saied, Jim Leder, Jeff Abell, Michel Lopez, and Phil Kramer. This paper benefited by reviews from Lynton Land and Joris Gieskes.

\section{REFERENCES}

Baker, P.A., and Kastner, M., 1981. Constraints on the formation of sedimentary dolomite. Science, 213:215-216.

Davies, P.J., McKenzie, J.A., Palmer-Julson, A., et al., 1991. Proc. ODP, Init. Repts., 133: College Station, TX (Ocean Drilling Program).

Ericson, E.K., 1976. Capricorn Basin. In Leslie, R.B., Evans, H.J., and Knight, C.L. (Eds.), Economic Geology of Australia and Papua New Guinea (Vol. 3). Australas. Inst. Mining and Metall. Monogr., 7:446-450.

Gieskes, J.M., Elderfield, H., and Palmer, M.R., 1986. Strontium and its isotopic composition in interstitial waters of marine carbonate sediments. Earth Planet. Sci. Lett., 77:229-235.

Hoffman, J.C., 1979. An evaluation of potassium uptake by Mississippi-Riverborne clays following deposition in the Gulf of Mexico [Ph.D. dissert.]. Case Western Reserve Univ., Cleveland, $\mathrm{OH}$.

Irwin, H., Curtis, C.D., and Coleman, M.L., 1977. Isotopic evidence for the source of diagenetic carbonates formed during burial of organic-rich sediments. Nature, 269:209-213.
Killingley, J.S., 1983. Effects of diagenetic recrystallization of ${ }^{18} \mathrm{O} /{ }^{16} \mathrm{O}$ values of deep-sea sediments. Nature, 301:594-597.

Lawrence, J.R., Gieskes, J.M., and Anderson, T.F., 1976. Oxygen isotope material balance calculations, Leg 35. In Hollister, C.D., Craddock, C., et al., Init. Repts. DSDP, 35: Washington (U.S. Govt. Printing Office), 507-512.

Perry, E.A., Jr., Beckles, E.C., and Newton, R.M., 1976. Chemical and mineralogical studies, Sites 322 and 325. In Hollister, C.D., Craddock, C., et al., Init. Repts. DSDP, 35: Washington (U.S. Govt. Printing Office), $465-469$.

Schlager, W., and James, N.P., 1978. Low-magnesian calcite limestones forming at the deep-sea floor, Tongue of the Ocean, Bahamas. Sedimentology, 25:675-702.

Swart, P.K., and Burns, S.J., 1990. Pore-water chemistry and carbonate diagenesis in sediments from Leg 115: Indian Ocean. In Duncan, R.A., Backman, J., Peterson, L.C., et al., Proc. ODP, Sci. Results, 115: College Station, TX (Ocean Drilling Program), 629-645.

Swart, P.K., and Guzikowski, M., 1988. Interstitial-water chemistry and diagenesis of periplatform sediments from the Bahamas, ODP Leg 101. In Austin, J.A., Jr., Schlager, W., Palmer, A.A., et al., Proc. ODP, Sci. Results, 101: College Station, TX (Ocean Drilling Program), 363-380.

\footnotetext{
Abbreviations for names of organizations and publications in ODP reference lists follow the style given in Chemical Abstracts Service Source Index (published by American
} Chemical Society).

Date of initial receipt: 21 September 1992

Date of acceptance: 20 January 1993

Ms 133SR-258

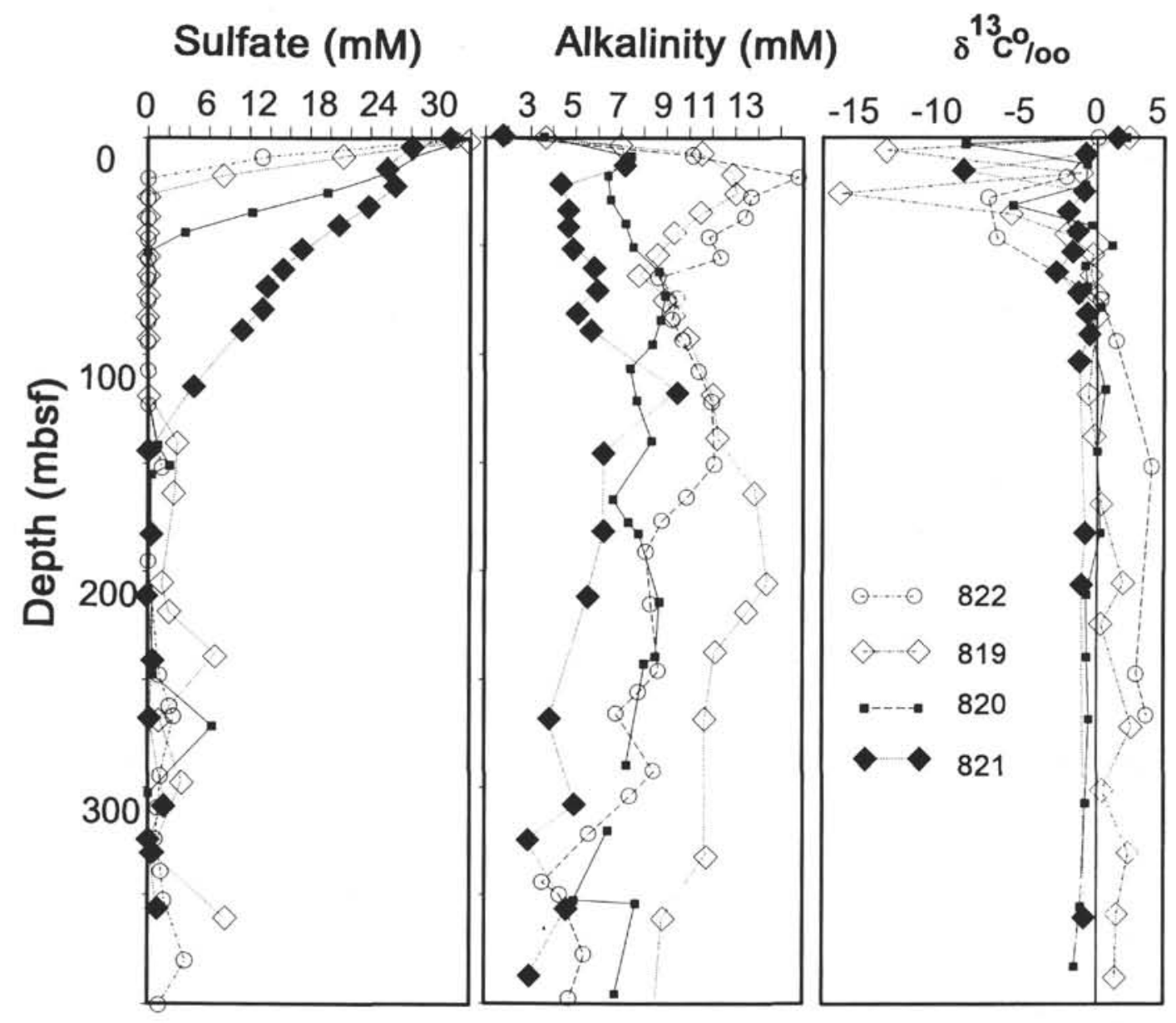

Figure 7. Sulfate, alkalinity, and carbon isotopic data from pore waters at Sites 819 through 822. 


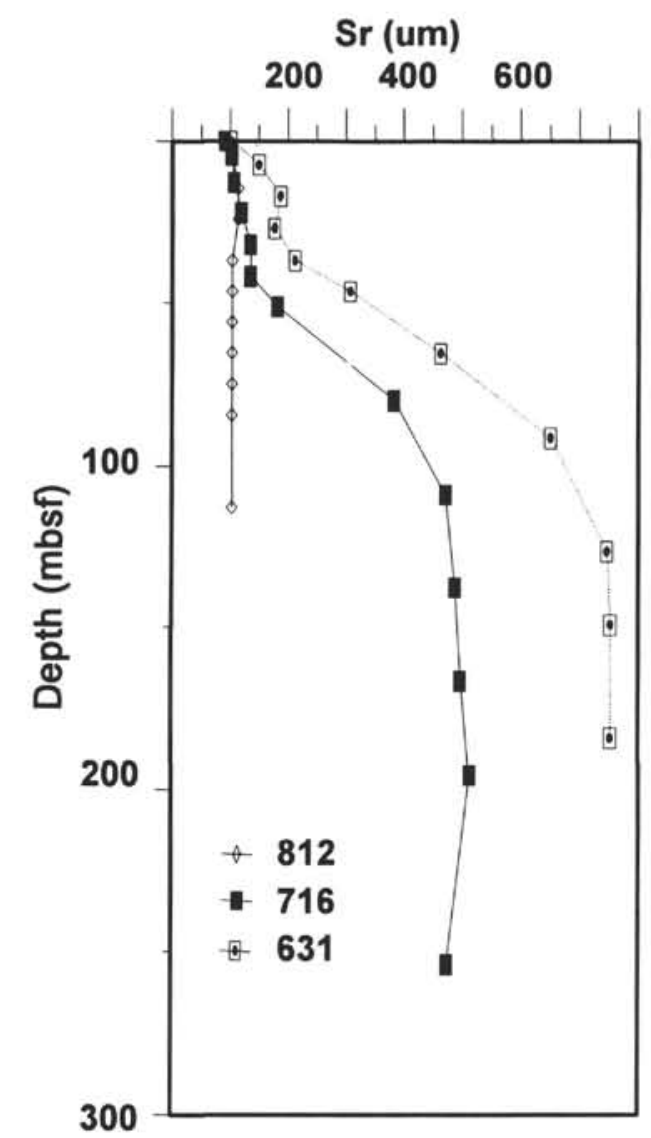

Figure 8. A comparison of the changes in the concentration of $\mathrm{Sr}^{2+}$ at Site 631 (Leg 101, Swart and Guzikowski, 1986), Site 716 (Leg 115, Swart and Burns, 1988), and Site 812 (Leg 133). Note the absence of an increase in $\mathrm{Sr}^{2+}$ at Site 812 compared with the other two sites.

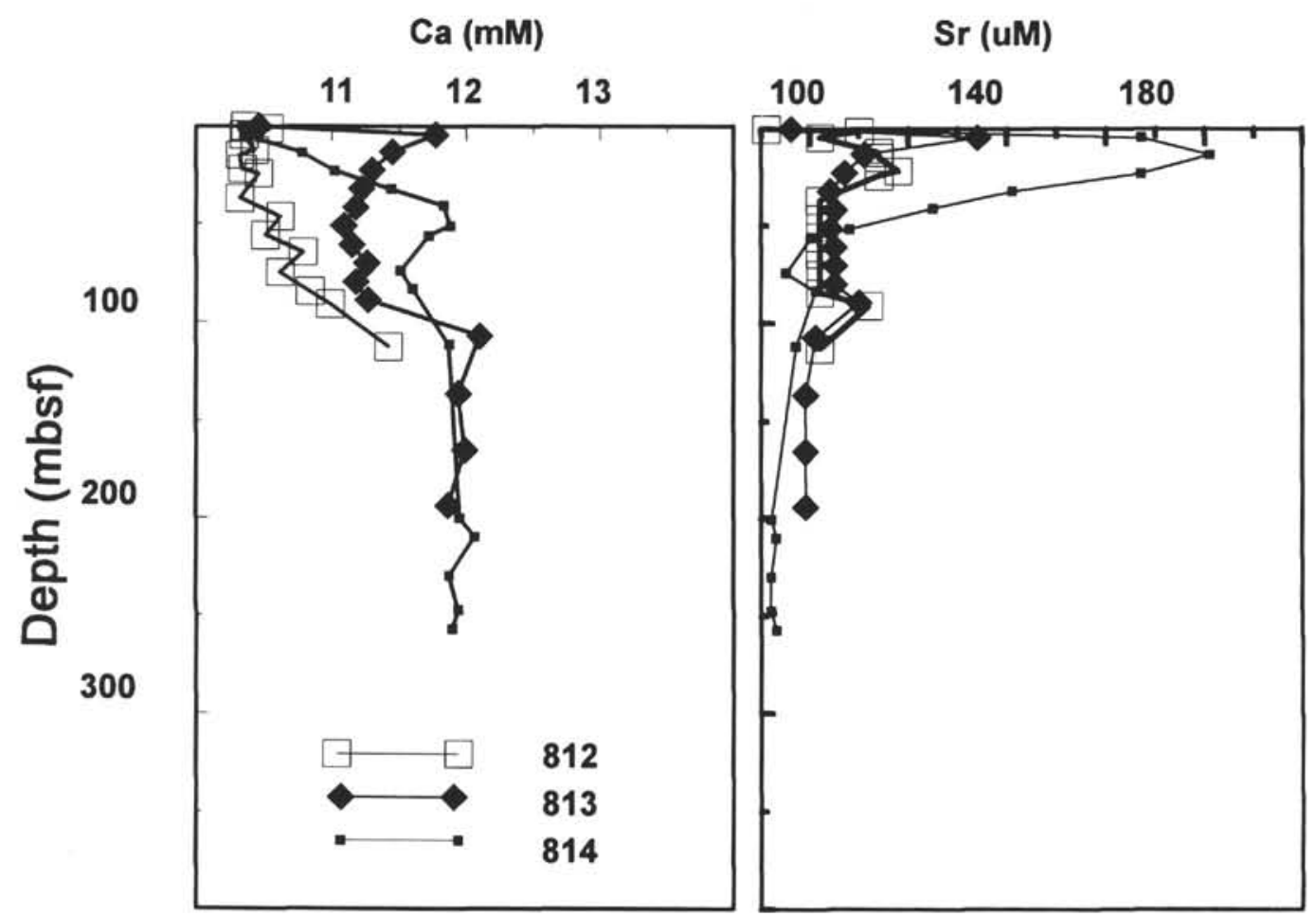

Figure 9. Interstitial pore-water calcium and strontium gradients from Sites 812 through 814 . 


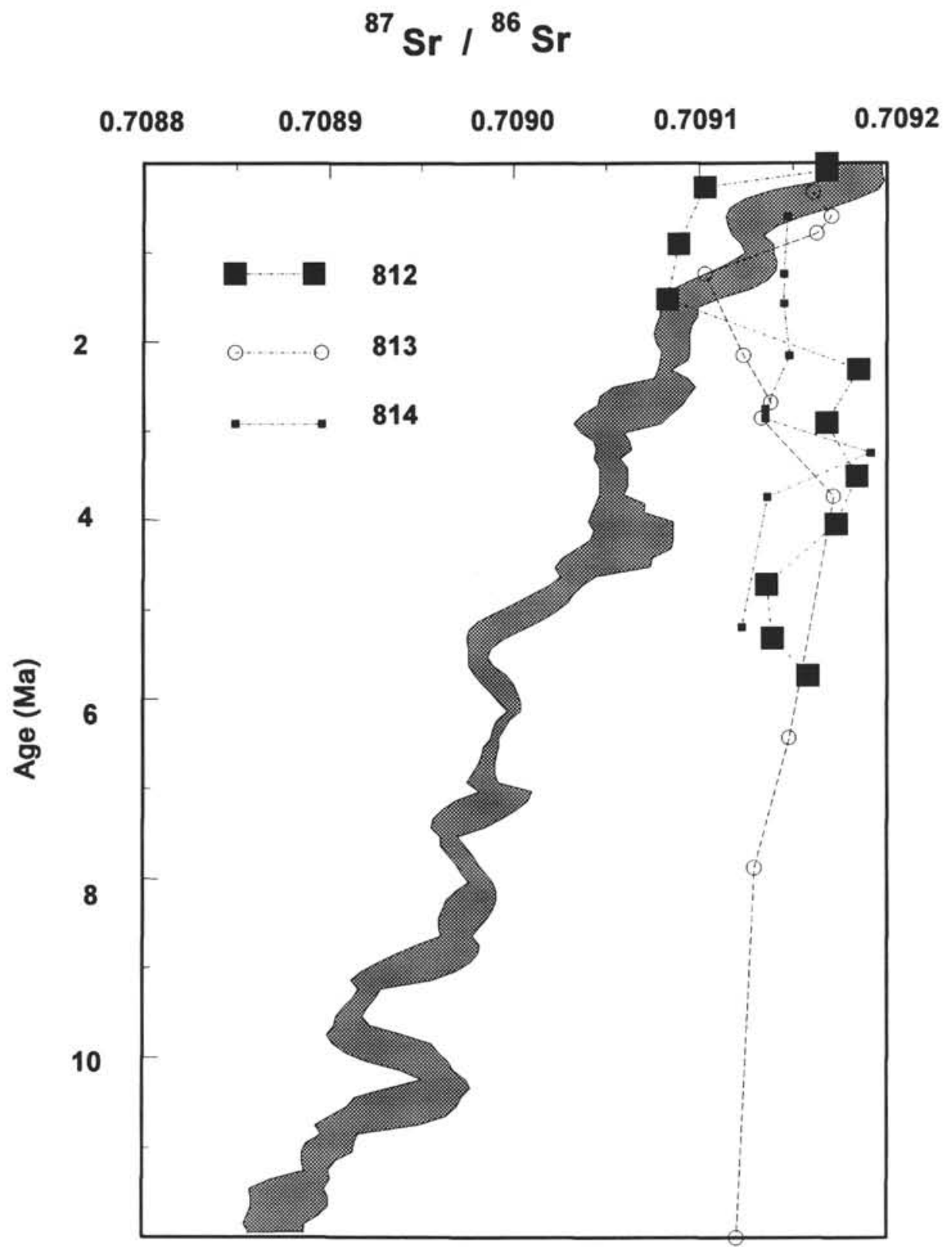

Figure 10. Strontium isotopic data from Sites 812 through 814 compared to contemporaneous seawater curve (gray shading). Note that most values are more radiogenic than contemporaneous seawater and are close to modern seawater values, suggesting circulation through the sediments (data from Elderfield et al., this volume). Dissolved $\mathrm{Sr}^{2+}$ profiles are shown in Figure 9. 

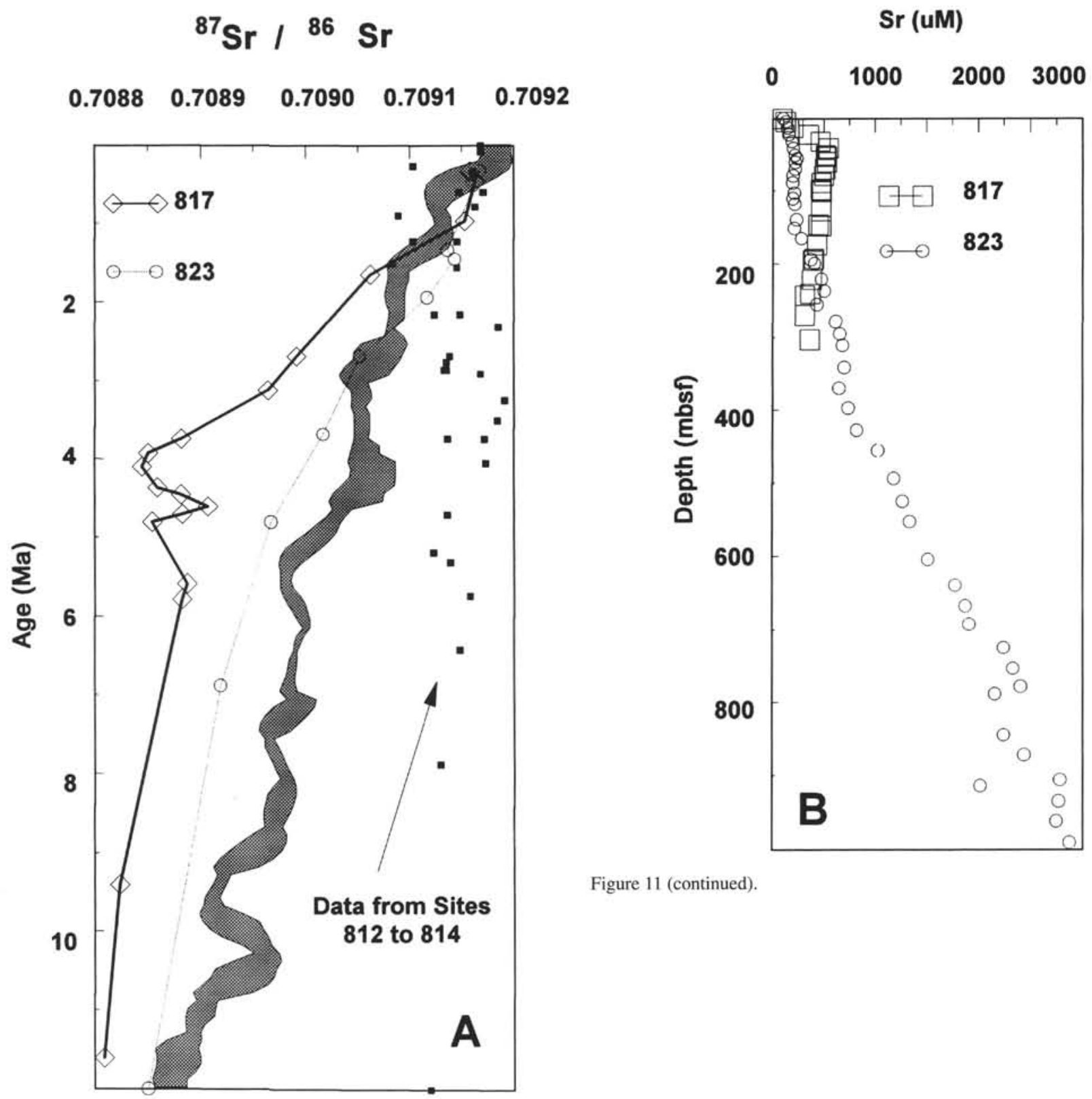

Figure 11 (continued).

Figure 11. A. Strontium isotopic data from Sites 817 and 823 compared to contemporaneous seawater curve (data from Elderfield et al., this volume). Also shown are data from Figure 9 for comparison. Strontium isotopic data fall below the seawater curve, in contrast to data from Sites 812 to 814 . B. Strontium concentration data from Sites 817 and 823. 


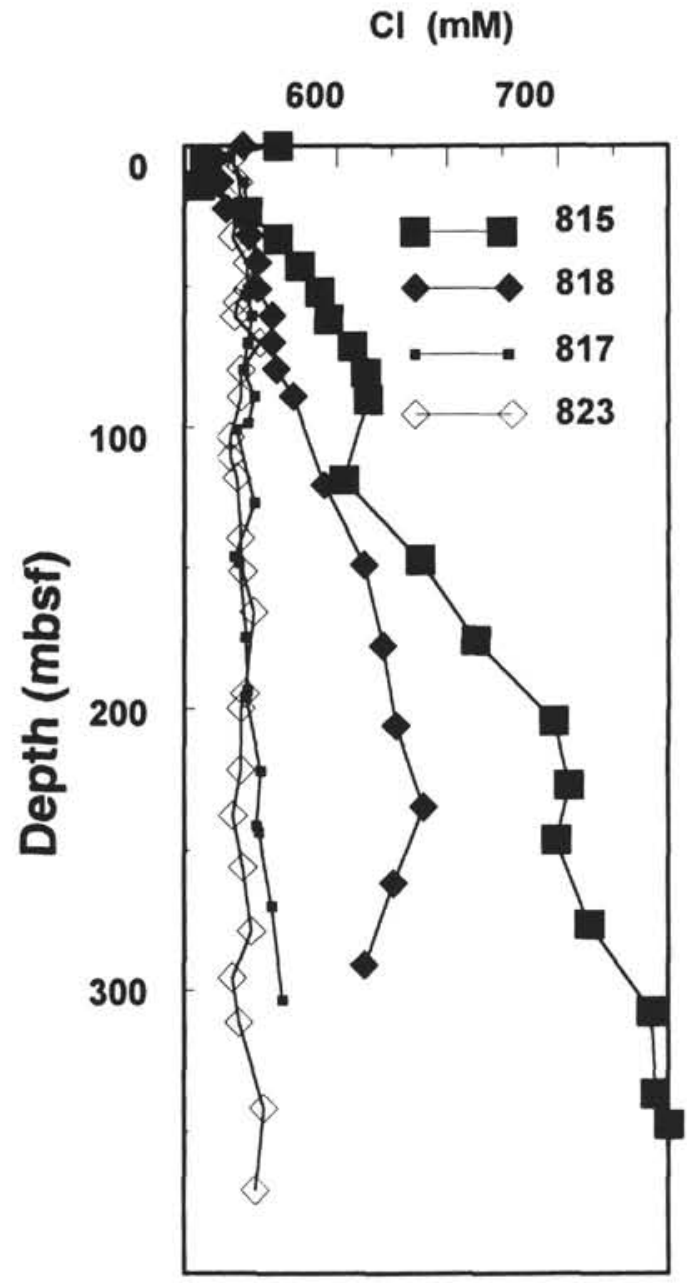

Figure 12. The concentrations of $\mathrm{Cl}^{-}$at Sites $815,817,818$, and 823. All sites exhibit a general increase in the lower portions of the hole. 
P.K. SWART, A. ISERN, H. ELDERFIELD, J.A. MCKENZIE

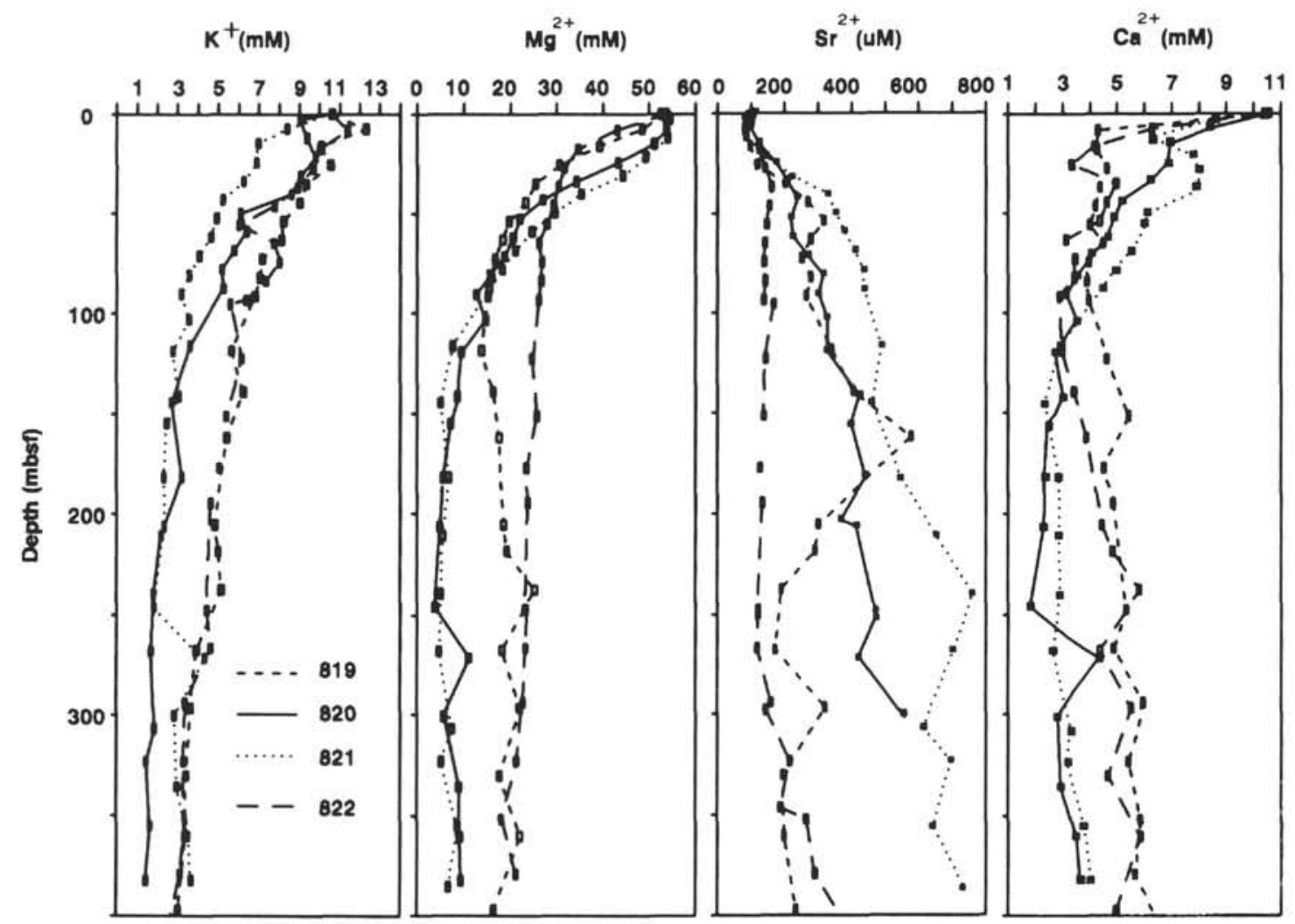

Figure 13. Changes in the concentrations of $\mathrm{K}^{+}, \mathrm{Mg}^{2+}, \mathrm{Sr}^{2+}$, and $\mathrm{Ca}^{2+}$ at Sites 819 through 822 . 


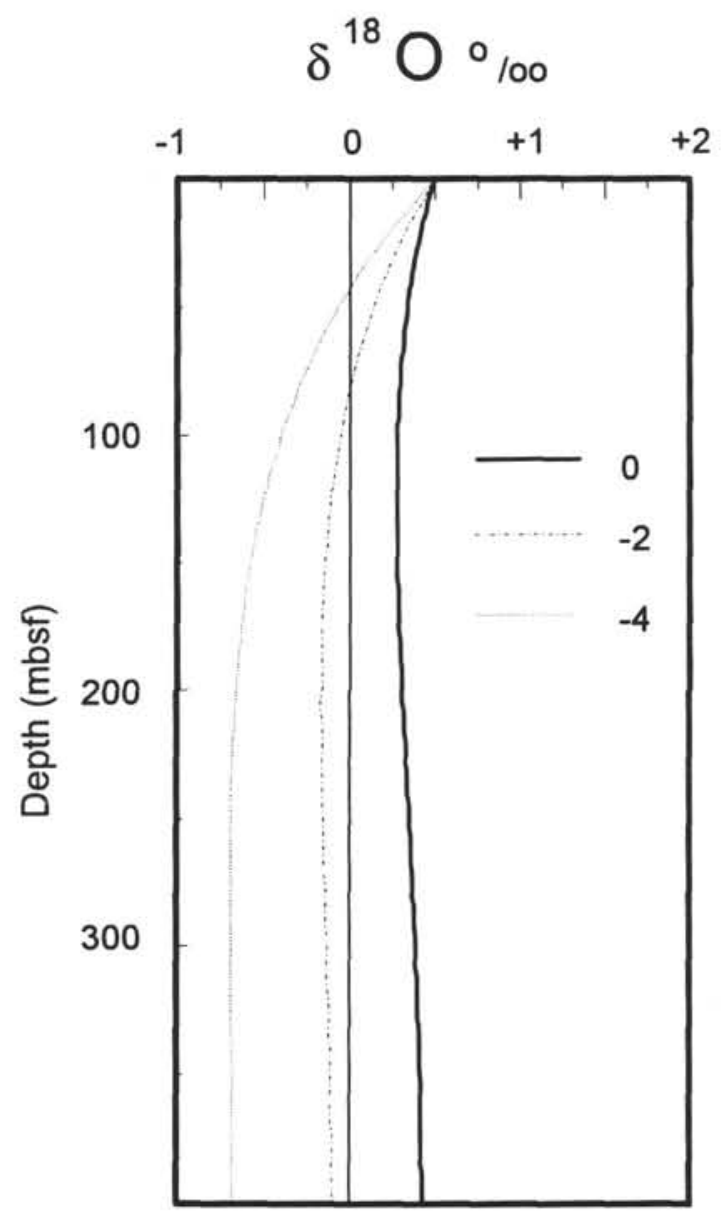

Figure 14. Hypothetical changes in the $\delta^{18} \mathrm{O}$ of pore waters with depth as a result of recrystallization of carbonates having different initial isotopic compositions. Note the similarity of the changes to the measured data in Figure 3. 